\title{
Possible Involvement of Hypothalamic Nucleobindin-2 in Hyperphagic Feeding in Tsumura Suzuki Obese Diabetes Mice
}

\author{
Shigeo Miyata, ${ }^{*, a \dagger}$ Nao Yamada,${ }^{a}$ and Tomie Kawada ${ }^{b}$ \\ ${ }^{a}$ Research Institute of Pharmaceutical Sciences, Faculty of Pharmacy, Musashino University; 1-1-20 Shin-machi, \\ Nishitokyo, Tokyo 202-8585, Japan: and ${ }^{b}$ Department of Clinical Pharmacy, Faculty of Pharmaceutical Sciences, \\ Niigata University of Pharmacy and Applied Life Sciences; 265-1 Higashizima, Akiha-ku, Niigata 956-8603, Japan. \\ Received June 6, 2012; accepted July 9, 2012
}

The aim of this study was to clarify the hypothalamic neuropeptides that are associated with hyperphagic feeding in Tsumura Suzuki Obese Diabetes (TSOD) mice, a model of type 2 diabetes with polygenic abnormalities. TSOD mice showed an increase in body weight and hyperleptinemia from 1 month of age and hyperphagic feeding, hyperglycemia, hyperlipidemia and hyperinsulinemia from 3 to 12 months of age compared with age-matched non-diabetic control Tsumura Suzuki Non Obesity (TSNO) mice. The mRNA level of nucleobindin-2 (NUCB2), the precursor of the anorexigenic neuropeptide nesfatin-1, was significantly decreased in the hypothalamus of TSOD mice compared with that in TSNO mice from 3 to 12 months of age. The protein level of NUCB2 was significantly decreased in the hypothalamus of TSOD mice compared with that in TSNO mice at 3 months of age. The mRNA levels of galanin, melanin-concentrating hormone, neuropeptide $Y$, and pro-opiomelanocortin were significantly changed in the hypothalamus in TSOD mice at several time points. Another model of type 2 diabetes, $d b / d b$ mice, which is a mutant mouse that lacks a functional leptin receptor, showed hyperphagic feeding but no change in hypothalamic NUCB2 mRNA compared with non-diabetic control $d b /+$ mice. The results suggest that the disrupted control of hypothalamic NUCB2-mediated signaling may contribute to hyperphagic feeding in TSOD mice. In addition, the mechanism for the development of hyperphagic feeding in TSOD mice is different than that in $d b / d b$ mice.

Key words hyperphagic feeding; nucleobindin-2; hypothalamus; obesity; diabetes

The world-wide prevalence of obesity and type 2 diabetes mellitus (T2DM) is increasing, and genetic analyses in humans are difficult since these conditions are also associated with environmental factors. Therefore, model animals are highly useful in biomedical studies and may lead to new insights into human obesity and T2DM.) Tsumura Suzuki Obese Diabetes (TSOD) mouse has been recently established as a model animal of obese T2DM by the selective breeding of ddY mice that show both obesity and urinary glucose. ${ }^{2)}$ The adiposity and significantly higher body mass index in TSOD mice compared to those in non-diabetic control Tsumura Suzuki Non Obesity (TSNO) mice are detected as early as 4 weeks of age, and are maintained until at least 18 months of age. $^{3,4)}$ TSOD mice showed a high level of blood glucose after the intraperitoneal injection of glucose and a blunted glucosestimulated insulin secretion compared with TSNO mice. ${ }^{5)}$ In addition, the hypoglycemic response to insulin treatment in TSOD mice was blunted compared to that in TSNO mice. ${ }^{5)}$ The insulin-stimulated uptake of $2-\left[{ }^{3} \mathrm{H}\right]$ deoxyglucose and translocation of glucose transporter-4 protein were impaired in skeletal muscle and adipose tissues in TSOD mice. ${ }^{6,7)}$ Thus, TSOD mice have both increased resistance to insulin and decreased insulin secretion in response to glucose. Genome-wide screening in TSOD mouse for loci linked to body weight and glucose homeostasis indicated that obesity and hyperglycemia are closely associated with three quantitative trait loci; Nidd4 on chromosome 11 interacts with the glucose level, Nidd5 on chromosome 2 interacts with both the insulin level and

\footnotetext{
The authors declare no conflict of interest.

${ }^{\dagger}$ Present address: Department of Psychiatry and Neuroscience, Gunma University Graduate School of Medicine; 3-39-22 Showa-machi, Maebashi, Gunma 371-8511, Japan.
}

body weight and Nidd6 on chromosome 1 interacts with body weight. ${ }^{3)}$ However, the critical genes and mechanisms for the development of obesity and T2DM have not yet been clarified.

Neuropeptide-mediated signals in the hypothalamus largely contribute to the sensing and integration of metabolic signals via circulating hormones, nutrients and adipokines, and drive the compensatory adjustments in caloric intake and energy expenditure that are necessary to restore body mass and body composition to an appropriate level. ${ }^{8,9)}$ Disruption of this system causes hyperphagic feeding, obesity and T2DM. ${ }^{10)}$ It has been reported that TSOD mice exhibit hyperphagic feeding compared with TSNO mice.7,11) Therefore, we hypothesized that the hypothalamic regulation of feeding was disrupted in TSOD mice, and the expression levels of hypothalamic neuropeptides are abnormal. However, no previous study has determined the expression profiles of hypothalamic neuropeptides in TSOD mice.

The aim of this study was to clarify the expression profiles of hypothalamic neuropeptides associated with hyperphagic feeding in TSOD mice. We assessed the following neuropeptides; agouti-related protein (AGRP), cocaine- and amphetamine-regulated transcript (CART), corticotropin releasing hormone $(\mathrm{CRH})$, galanin $(\mathrm{GAL})$, gastrin releasing peptide (GRP), melanin-concentrating hormone $(\mathrm{MCH})$, neuromedin $\mathrm{S}$ (NMS), neuromedin $\mathrm{U}$ (NMU), neuropeptide $\mathrm{B}$ (NPB), neuropeptide S (NPS), neuropeptide W (NPW), neuropeptide Y (NPY), nucleobindin 2 (NUCB2), orexin (ORX), pituitary adenylate cyclase-activating polypeptide (PACAP), pro-opiomelanocortin (POMC), tyrotropin releasing hormone (TRH), urocortin (UCN), urocortin 2 (UCN2) and urocortin 3 (UCN3). ${ }^{12-31)}$ We also evaluated the hypothalamic level of NUCB2 mRNA, a candidate associated with hyperphagic feeding in TSOD mice, in another model of T2DM, $d b / d b$ 
mice, compared with that in non-diabetic control $d b /+$ mice.

\section{MATERIALS AND METHODS}

Animals Male TSOD, TSNO, $d b / d b$ and $d b /+$ mice were purchased from the Institute for Animal Reproduction (Ibaraki, Japan). Each cage housed 2-3 mice that had free access to food (MF; Oriental Yeast Co., Ltd.) and water. The animal room was maintained at $23 \pm 2{ }^{\circ} \mathrm{C}$ and $55 \pm 10 \%$ humidity under a 12-h light-dark cycle (light on at 8:00 and light off at 20:00). The animals were acclimatized to the laboratory environment at least for 1 week before the experiment. This study was carried out in accordance with the Guide for the Care and Use of Laboratory Animals, as adopted by the Committee on the Care and Use of Laboratory Animals of Musashino University.

Food Intake Mice were transferred to individual acryl cages $(14 \times 23 \times 15 \mathrm{~cm}$; CLEA Japan, Inc.) equipped with a food-intake monitor (BioDAQ Unplugged, Research Diets Inc.) and a water bottle at 8:00, and the measurement was then started. The mice had free access to food pellets (MF; Oriental Yeast Co., Ltd.) and water. Twenty-four hours later, the mice were removed to their home cages. Food intake over $24 \mathrm{~h}$ was calculated as the difference between the weight of food before and after measurement. One day later, the mice were used in assays of blood chemistry.

Blood Chemistry Blood was collected from the vena cava under pentobarbital $(50 \mathrm{mg} / \mathrm{kg}$, intraperitoneally (i.p.))

Table 1. Primer Sequences Used This Study

\begin{tabular}{|c|c|c|c|c|c|}
\hline Gene name & Abbreviation & Primer sequence & $\begin{array}{l}\text { Amplicon size } \\
\text { (bp) }\end{array}$ & Function & Accession number \\
\hline Agouti-related protein & AGRP & $\begin{array}{l}\text { Forward ccgettcttcaatgectttt } \\
\text { Reverse attctcatccectgectttg }\end{array}$ & 109 & Orexigenic & NM_007427 \\
\hline $\begin{array}{l}\text { Cocain- and amphetamine- } \\
\text { regulated transcript }\end{array}$ & CART & $\begin{array}{l}\text { Forward aagtttgcgttcccctcaga } \\
\text { Reverse tgcacacacaccaacaccat }\end{array}$ & 113 & Anorexigenic & NM_013732 \\
\hline Corticotropin releasing hormone & $\mathrm{CRH}$ & $\begin{array}{l}\text { Forward tcagcaagctcacagcaaca } \\
\text { Reverse cggagctgcgatatggtaca }\end{array}$ & 141 & Anorexigenic & NM_205769 \\
\hline Galanin & GAL & $\begin{array}{l}\text { Forward gaacagcgetggctaccttc } \\
\text { Reverse actccetcttgectgtgagg }\end{array}$ & 89 & Orexigenic & NM_010253 \\
\hline Gastrin releasing peptide & GRP & $\begin{array}{l}\text { Forward gatgaatcccegtccetgta } \\
\text { Reverse aaatccettgcagcttcttcc }\end{array}$ & 92 & Anorexigenic & NM_175012 \\
\hline Melanin-concentrating hormone & $\mathrm{MCH}$ & $\begin{array}{l}\text { Forward tgcagaaagatccgttgtcg } \\
\text { Reverse agtggcagcccgtgagttac }\end{array}$ & 135 & Orexigenic & NM_029971 \\
\hline Neuromedin $\mathrm{S}$ & NMS & $\begin{array}{l}\text { Forward tgctggaagactgtgggaatag } \\
\text { Reverse ttgttccatgcccaaatcag }\end{array}$ & 74 & Anorexigenic & NM_001011684 \\
\hline Neuromedin U & NMU & $\begin{array}{l}\text { Forward actgagggagctttgccgta } \\
\text { Reverse aacggatgcacaacagagga }\end{array}$ & 150 & Anorexigenic & NM_019515 \\
\hline Neuropeptide B & NPB & $\begin{array}{l}\text { Forward acgtcttcttgtcgctgcac } \\
\text { Reverse cttcaagcaagactgggcata }\end{array}$ & 110 & Anorexigenic & NM_153288 \\
\hline Neuropeptide S & NPS & $\begin{array}{l}\text { Forward tcggetttgatcttgagtcg } \\
\text { Reverse tacctgccactgcacttggt }\end{array}$ & 102 & Anorexigenic & NM_001163611 \\
\hline Neuropeptide W & NPW & $\begin{array}{l}\text { Forward gctgctagagccttcggaga } \\
\text { Reverse tgacaggatcggcaaagatg }\end{array}$ & 76 & Anorexigenic & NM_001099664 \\
\hline Neuropeptide Y & NPY & $\begin{array}{l}\text { Forward ccatgtggtgatgggaaatg } \\
\text { Reverse gggacaggcagactggtttc }\end{array}$ & 94 & Orexigenic & NM_023456 \\
\hline Nucleobindin-2 & NUCB2 & $\begin{array}{l}\text { Forward tggcatgaatcaccaccttc } \\
\text { Reverse ccgagtccggtcatattgct }\end{array}$ & 136 & Anorexigenic & NM_001130479 \\
\hline Orexin & ORX & $\begin{array}{l}\text { Forward tccttcaggccaacggtaac } \\
\text { Reverse gggtgctaaagcggtggtag }\end{array}$ & 128 & Orexigenic & NM_010410 \\
\hline $\begin{array}{l}\text { Pituitary adenylate cyclase-acti- } \\
\text { vating polypeptide }\end{array}$ & PACAP & $\begin{array}{l}\text { Forward aggctagggcaattggaaca } \\
\text { Reverse tgtcaggcagtggaacctaca }\end{array}$ & 141 & Anorexigenic & NM_009625 \\
\hline Pro-opiomelanocortin & POMC & $\begin{array}{l}\text { Forward ggettgcaaactcgacctct } \\
\text { Reverse cggaagtgacccatgacgta }\end{array}$ & 105 & Anorexigenic & NM_008895 \\
\hline Thyrotropin releasing hormone & TRH & $\begin{array}{l}\text { Forward tcagggaacctctggaggag } \\
\text { Reverse gggtttgggtggatgetatg }\end{array}$ & 146 & Anorexigenic & NM_009426 \\
\hline Urocortin & $\mathrm{UCN}$ & $\begin{array}{l}\text { Forward gtccatcgacctcaccttcc } \\
\text { Reverse aagggtcaaggctttcgtga }\end{array}$ & 151 & Anorexigenic & NM_021290 \\
\hline Urocortin 2 & $\mathrm{UCN} 2$ & $\begin{array}{l}\text { Forward gccagccettacctagacacc } \\
\text { Reverse cggccaacatgggctagtat }\end{array}$ & 143 & Anorexigenic & NM_145077 \\
\hline Urocortin3 & UCN3 & $\begin{array}{l}\text { Forward getgatgeccacctacttcc } \\
\text { Reverse gtgggagaggettgtcettg }\end{array}$ & 70 & Anorexigenic & NM_031250 \\
\hline Peptidylpropyl isomerase A & PPIA & $\begin{array}{l}\text { Forward tgtggtctttgggaaggtga } \\
\text { Reverse gtaaaatgcccgcaagtcaa }\end{array}$ & 144 & Endogenous control & NM_008907 \\
\hline
\end{tabular}

The feeding-regulated neuropeptide genes are listed alphabetically. 


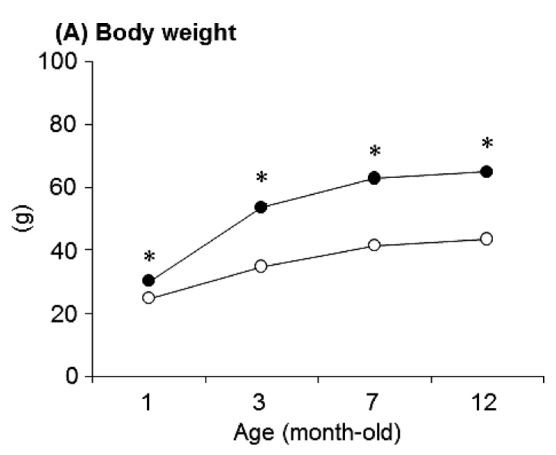

(C) Glucose

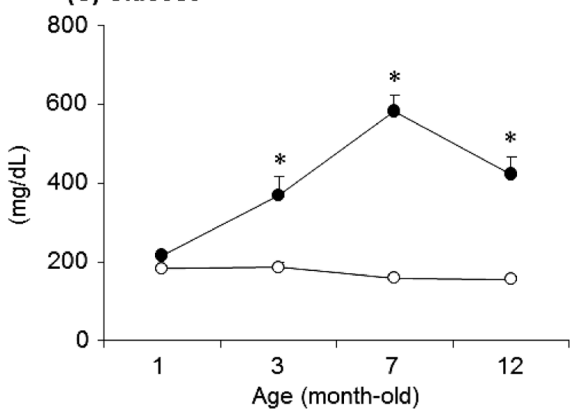

(E) Total cholesterol

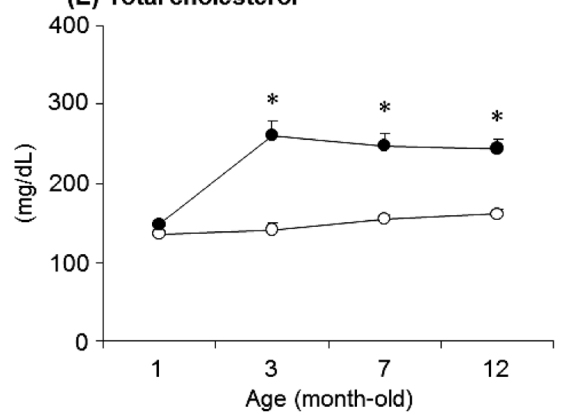

(G) Leptin

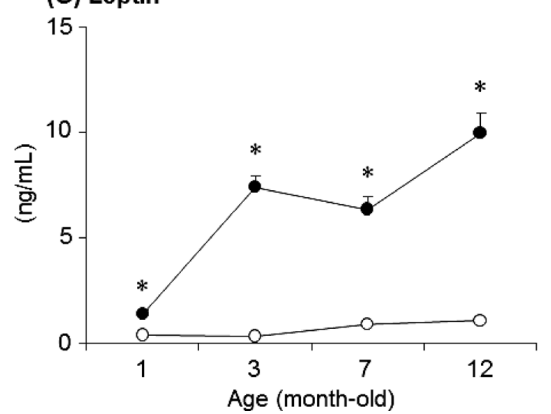

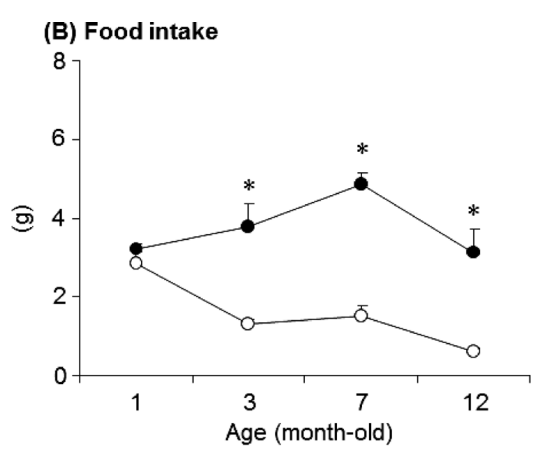

(D) Triglyceride
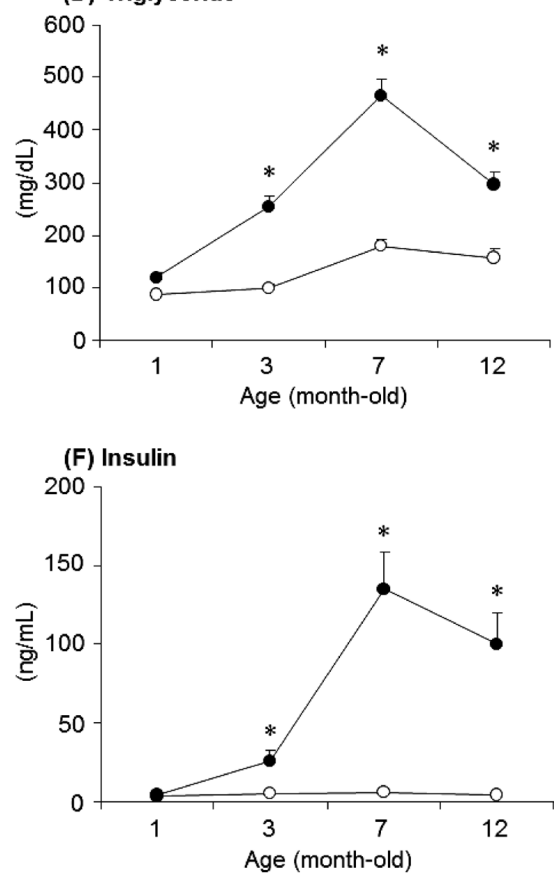

Fig. 1. Growth Curves of TSOD and TSNO Mice Showing Body Weight (A), Food Intake (B) and Plasma Levels of Glucose (C), Triglyceride (D), Total Cholesterol (E), Insulin (F) and Leptin (G)

Each point represents the mean with S.E.M. of TSOD (closed circles) and TSNO (open circles) mice. There were 10 animals in each group, except for TSOD mice at 12 months $(n=9)$, since one mouse died before the experiment. $* p<0.05$ v. age-matched TSNO mice (Tukey-Kramer's test).

anesthesia. Blood sampling was performed between 14:00 and 16:00. The collected blood was gently mixed with ethylenediaminetetraacetic acid (EDTA) and centrifuged at $1000 \times \mathbf{g}$ for $10 \mathrm{~min}$ at $4^{\circ} \mathrm{C}$. The obtained plasma samples were immediately frozen and stored at $-80^{\circ} \mathrm{C}$ until use. The plasma levels of glucose, triglyceride, total cholesterol, insulin and leptin were measured by commercially available biochemical kits; Glucose C-II Test-Wako, Triglyceride E Test-Wako, Cholesterol E Test-Wako (Wako Pure Chemical Industries, Ltd.), Mouse Insulin ELISA KIT (T-Type) (AKRIN-011T, Shibayagi
Co., Ltd.) and Mouse Leptin ELISA KIT (AKRLP-011, Shibayagi Co., Ltd.) according to the respective manufacturer's directions.

Quantitative Real-Time Polymerase Chain Reaction (PCR) Assay The expression level of feeding-regulated neuropeptide mRNA was measured by a reverse transcription real-time PCR assay. Mice were killed by decapitation and the hypothalamus was quickly dissected. The obtained tissues were immediately frozen and stored at $-80^{\circ} \mathrm{C}$ until use. Tissue sampling was performed between 14:00 and 16:00. 
(A) NUCB2

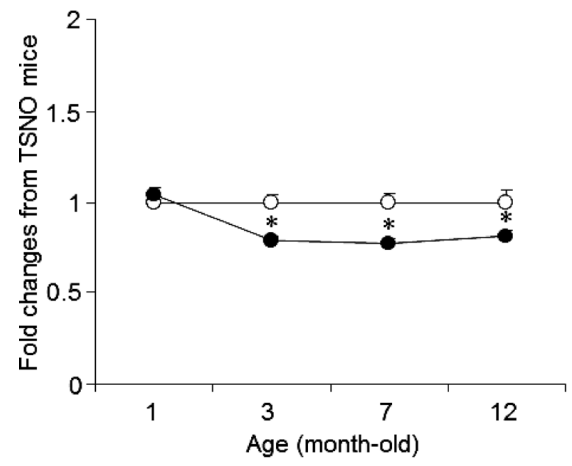

(C) GAL

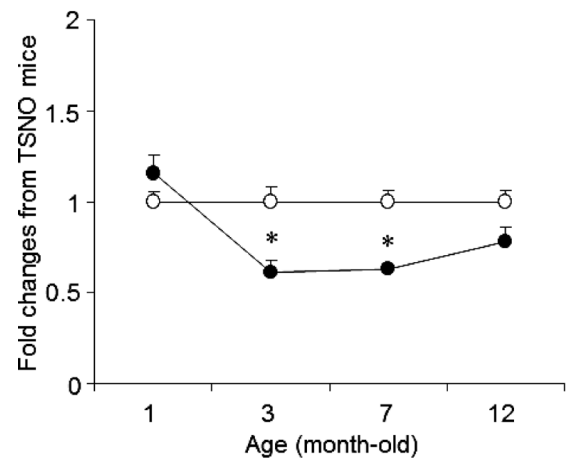

(E) POMC

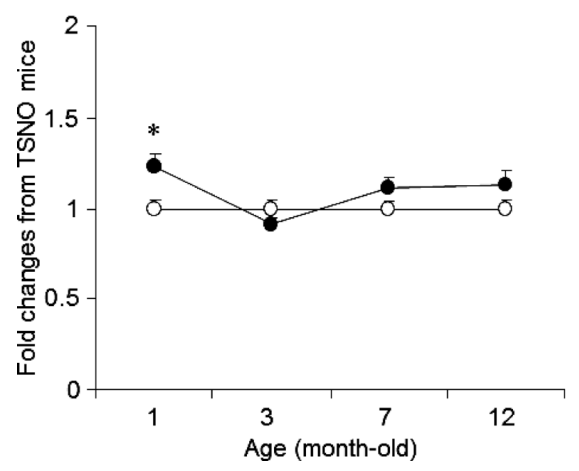

(B) NPY

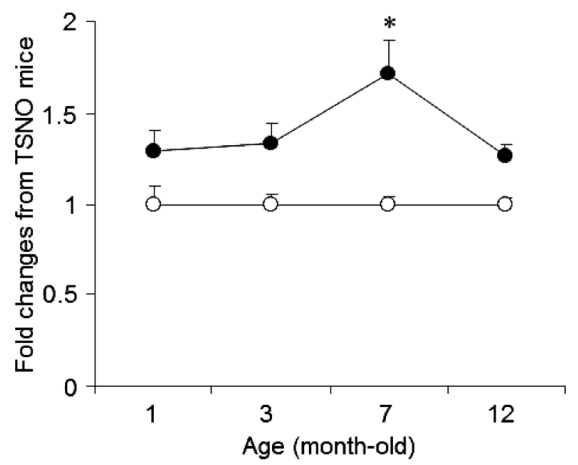

(D) $\mathrm{MCH}$

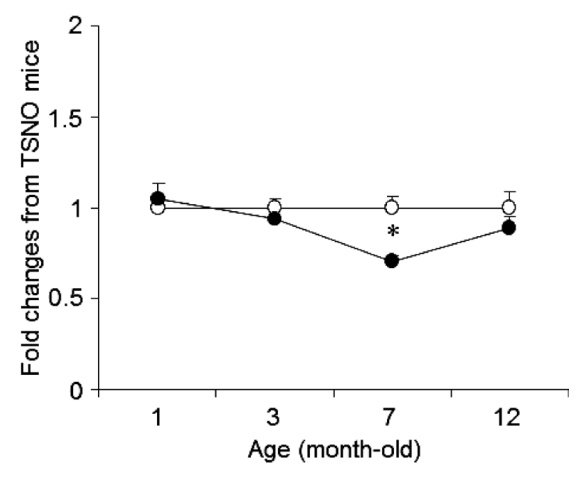

3, 7 and 12 Months of Age

Each point represents the mean with S.E.M. in TSOD (closed circles; $n=7$ ) and TSNO (open circles; $n=7$ ) mice. * $p<0.05 v s$. age-matched TSNO mice (Tukey's test).

Total RNA was extracted from the hypothalamic tissues using the FavorPrep Tri-RNA reagent (FAVORGEN Biotech Corp.) according to the manufacturer's directions. cDNA was synthesized by the PrimeScript RT reagent Kit (Takara Bio Inc.) using $1 \mu \mathrm{g}$ total RNA and oligo dT primer. Synthesized cDNA was mixed with SYBR Premix Ex Taq II (Takara Bio Inc.) and the specific primers. Amplification of the genes consisted of 50 cycles, each at $95^{\circ} \mathrm{C}$ for $3 \mathrm{~s}$ and $60^{\circ} \mathrm{C}$ for $30 \mathrm{~s}$ in a real-time PCR quantitative system (7500Fast Real-Time PCR System, Applied Biosystems Japan Ltd.). The amounts of target genes relative to that of the invariant control gene for peptidylpropyl isomerase A were calculated for data analysis. The data are shown as the fold change from the mean values of the respective age-matched non-diabetic control mice. Sequences of the primers are listed in Table 1.

Western Blot TSOD and TSNO mice at 3 months of age were killed by decapitation. The hypothalamus was quickly dissected and the obtained tissues were immediately frozen and stored at $-80^{\circ} \mathrm{C}$ until use. The tissues were homogenized in ice-cold buffered sucrose $(0.32 \mathrm{M})$ solution containing $20 \mathrm{~mm}$ Tris- $\mathrm{HCl}(\mathrm{pH} 7.5)$, protease inhibitor cocktail (P8340, Sigma-Aldrich, Inc.) and phosphatase inhibitor cocktail (Nacalai Tesque, Inc.). The homogenates were centrifuged at $1000 \times \boldsymbol{g}$ for $10 \mathrm{~min}$ at $4^{\circ} \mathrm{C}$, and the resulting supernatants were re-centrifuged at $20000 \times \boldsymbol{g}$ for $10 \mathrm{~min}$ at $4^{\circ} \mathrm{C}$. The obtained supernatants were ultracentrifuged at $100000 \times \mathrm{g}$ for $60 \mathrm{~min}$ at $4^{\circ} \mathrm{C}$, and the resulting supernatants were collected as the protein samples. The protein concentrations were determined using a Dc Protein assay kit (Bio-Rad).

The protein samples were diluted with electrophoresis sample buffer. Proteins were separated by sodium dodecyl sulfate (SDS)-polyacrylamide gels and transferred to a polyvinylidene 
(A) AGRP

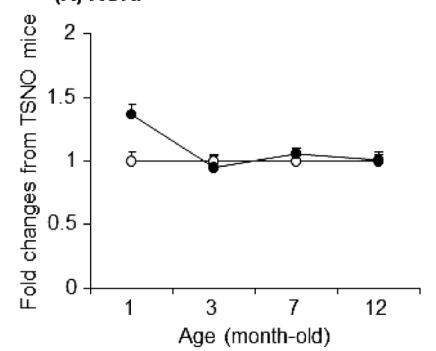

(D) GRP

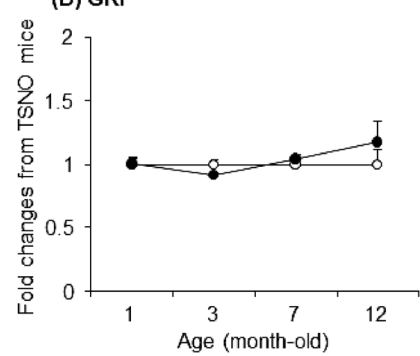

(G) NPB

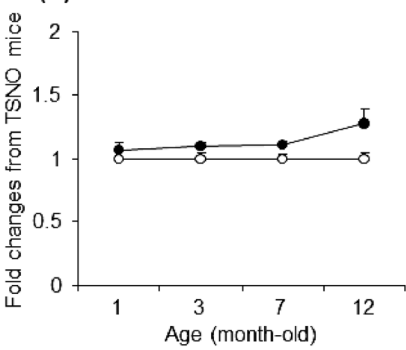

(J) ORX

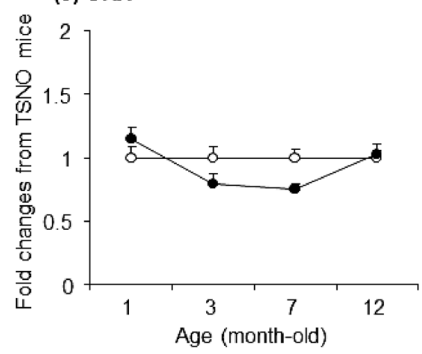

(M) UCN

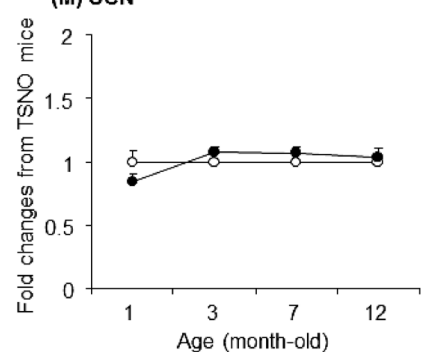

(B) CART

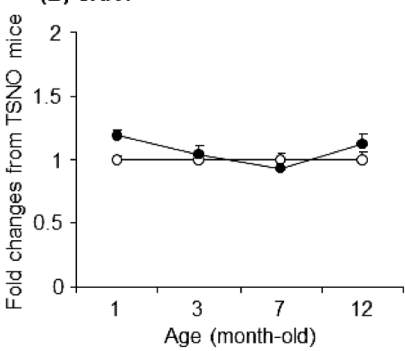

(E) NMS

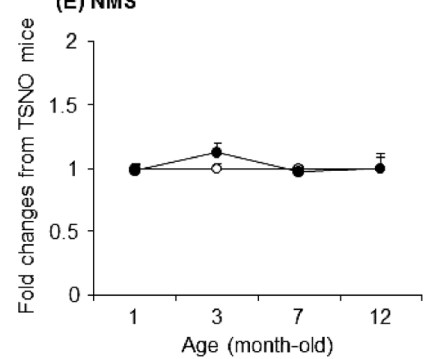

(H) NPS

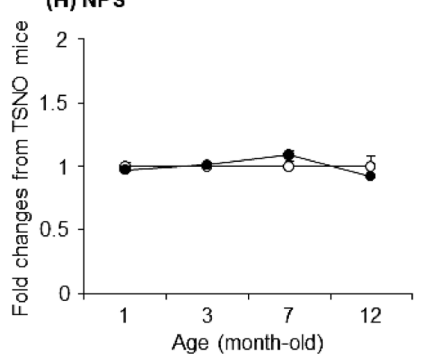

(K) PACAP

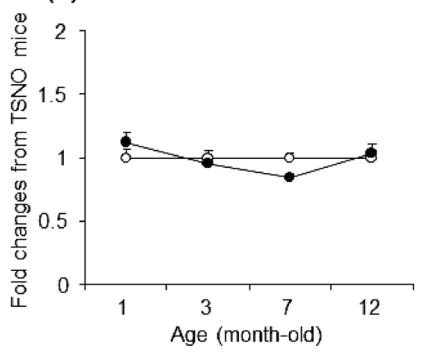

(N) UCN2

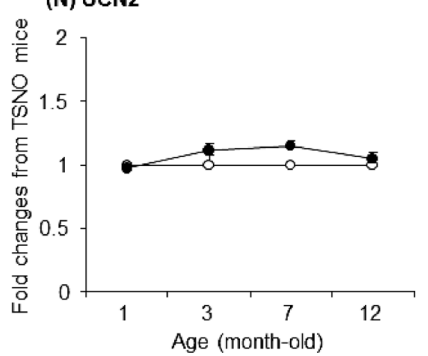

(C) $\mathrm{CRH}$

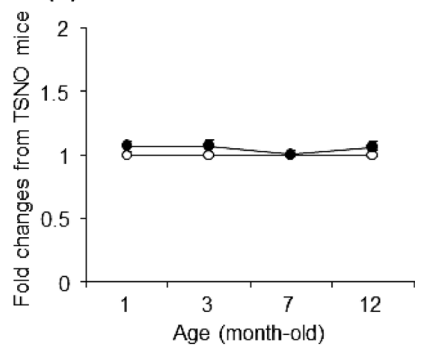

(F) NMU

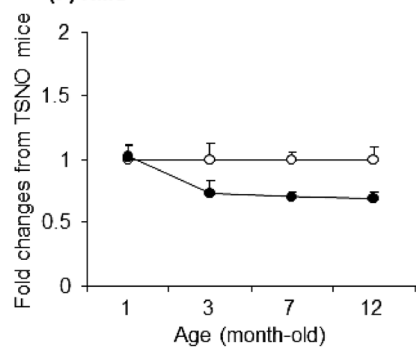

(I) NPW

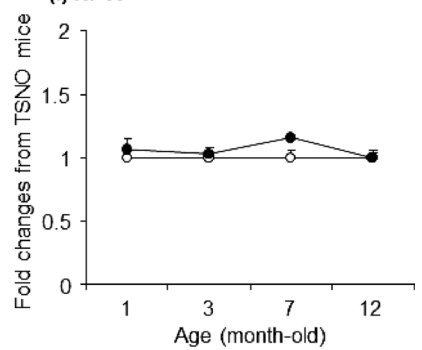

(L) TRH

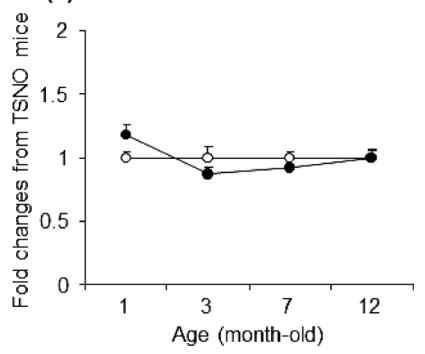

(O) UCN3

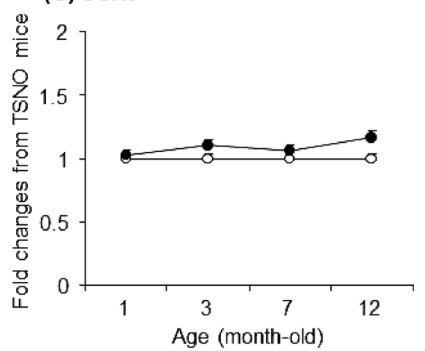

Fig. 3. Expression Levels of the Other Neuropeptide mRNA in the Hypothalamus of TSOD and TSNO Mice at the 1, 3, 7 and 12 Months of Age Each point represents the mean with S.E.M. TSOD (closed circles; $n=7$ ) and TSNO (open circles; $n=7$ ) mice.

difluoride (PVDF) membrane. Blots were probed with antibodies to NUCB2 $(1: 2000$, N9414, Sigma-Aldrich, Inc.) and glyceraldehyde-3-phosphate dehydrogenase (GAPDH) (1:10000, G9545, Sigma-Aldrich, Inc.). Immunoblots were developed using horseradish peroxidase-conjugated 2nd antibodies (GE Healthcare), and then detected with chemiluminescence reagents and visualized by an LAS-3000 lumino-image analysis system (FUJIFILM Co., Ltd.).

Statistical Analysis The data are expressed as the means with standard error of the mean (S.E.M.). Statistical significance was determined by the two-way analysis of variance (ANOVA) followed by the post-hoc Tukey's and Tukey-Kramer's tests for multiple comparisons. The significance of differences between two groups was determined by Student's $t$-test and Aspin-Welch's $t$-test. $p$ Values less than 0.05 were considered significant. 

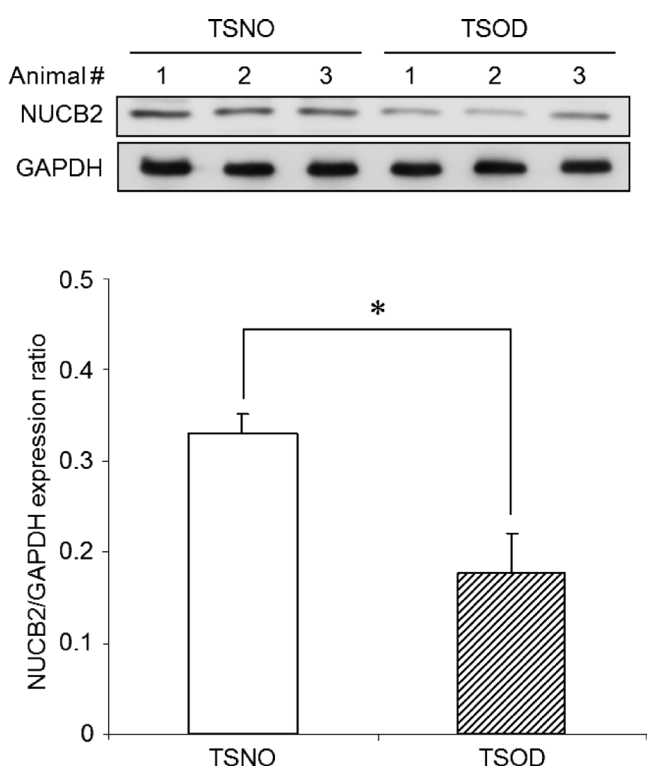

Fig. 4. Protein Levels of NUCB2 in the Hypothalamus of TSNO and TSOD Mice at 3 Months of Age

GAPDH was measured as the endogenous control. Each column represents the mean of the NUCB2/GAPDH expression ratio with S.E.M. in TSOD (hatched column; $n=3$ ) and TSNO (open column; $n=3$ ) mice. ${ }^{*} p<0.05 v s$. TSNO mice $(t$-test).

\section{RESULTS}

Growth Curves in TSOD and TSNO Mice The body weight in TSOD mice was significantly higher than that in TSNO mice as early as 1 month of age, and this difference was maintained until 12 months of age (Fig. 1A). Food intake (Fig. 1B) and plasma levels of glucose (Fig. 1C), triglyceride (Fig. 1D), total cholesterol (Fig. 1E), and insulin (Fig. 1F) were significantly higher in TSOD mice than TSNO mice at 3, 7 and 12 months of age, but not at 1 month of age. The plasma leptin level in TSOD mice was significantly higher than that in TSNO mice at 1-12 months of age (Fig. 1G).

Differences in the Expression of Hypothalamic Neuropeptide mRNA between TSOD Mice and Age-Matched TSNO Mice We analyzed the cDNA levels of 20 neuropeptides (Table 1) in the hypothalamus of TSOD mice at $1,3,7$ and 12 months of age and compared them with the respective values in age-matched TSNO mice. Two-way ANOVA revealed that the cDNA levels of GAL $\left(F_{1,48}=17.638, p<0.001\right)$, $\mathrm{MCH}\left(F_{1,48}=5.435, p<0.05\right)$, NMU $\left(F_{1,48}=12.719, p<0.001\right)$, $\mathrm{NPB}\left(F_{1,48}=9.886, p<0.01\right), \mathrm{NPY} \quad\left(F_{1,48}=37.374, p<0.001\right)$, NUCB2 $\quad\left(F_{1,48}=29.140, \quad p<0.001\right), \quad$ POMC $\quad\left(F_{1,48}=6.709\right.$, $p<0.05)$, UCN2 $\left(F_{1,48}=4.875, p<0.05\right)$ and UCN3 $\left(F_{1,48}=9.799\right.$, $p<0.01)$ were significantly different between TSOD and TSNO mice. Among them, the post-hoc analysis revealed that the cDNA levels of NUCB2, NPY, GAL, MCH and POMC were significantly different between TSOD and TSNO mice at several ages (Fig. 2), while there were no significant changes in the other neuropeptides (Fig. 3). The NUCB2 cDNA level was significantly decreased in TSOD mice compared with that in TSNO mice at 3, 7 and 12 months of age (Fig. 2A). The NPY cDNA level was significantly increased in TSOD mice at 7 months of age compared with that in TSNO mice (Fig. 2B). The GAL cDNA level was significantly decreased in TSOD mice at 3 and 7 months of age compared with that in TSNO mice (Fig. 2C). The MCH cDNA level was significantly decreased in TSOD mice at 7 months of age compared with that in TSNO mice (Fig. 2D). The POMC cDNA level in TSOD mice was significantly increased compared with that in TSNO mice only at 1 month of age (Fig. 2E).

Protein Level of Hypothalamic NUCB2 in TSOD Mice Based on the expression profiles of neuropeptide cDNA, we focused on NUCB2 as a candidate that interacted with hyperphagic feeding in TSOD mice. Therefore, we next assessed the protein level of NUCB2 in the hypothalamus of TSOD mice at 3 months of age. As a result, the protein level of NUCB2, but not the endogenous control protein GAPDH, was markedly decreased in the hypothalamus of TSOD mice compared with that in TSNO mice (Fig. 4).

Hypothalamic Expression of NUCB2, NPY, GAL, MCH and POMC mRNA in $\boldsymbol{d} \boldsymbol{b} / \boldsymbol{d} \boldsymbol{b}$ Mice $d b / d b$ mice exhibited higher levels of body weight, food intake and plasma glucose, triglyceride, total cholesterol, insulin and leptin than $d b /+$ mice (Fig. 5). The NPY cDNA level was significantly increased in $d b / d b$ mice compared with $d b /+$ mice (Fig. 6). However, there was no difference in cDNA level of NUCB2, GAL, MCH or POMC between these groups (Fig. 6).

\section{DISCUSSION}

At 1 month of age, TSOD mice exhibited slight but significant increases in body weight and the plasma leptin level compared with those in TSNO mice. However, there was no change in food intake or the plasma levels of glucose, triglyceride, total cholesterol or insulin between TSOD mice and TSNO mice. Therefore, TSOD mice at 1 month of age have not yet developed T2DM. TSOD mice exhibited marked increases in body weight and plasma levels of glucose, triglyceride, total cholesterol, insulin and leptin from 3 months to 12 months of age, indicating that TSOD mice exhibit the T2DM phenotype after 3 months of age. In addition, hyperphagic feeding was observed in TSOD mice after 3 months of age. Therefore, the hyperphagic feeding in TSOD mice is consistent with the period in which they show the T2DM phenotype. In this study, the food intake in TSNO mice was decreased age-dependently. It has been reported that aged mice demonstrate increase in food spilling but decrease in the actual food consumption. ${ }^{32)}$ We assessed the food intake in mice by the food-intake monitor which could measure the actual food consumption in mice. Therefore, it is unlikely that the decreased food intake in TSNO mice is due to the methodological problem.

The hypothalamus receives metabolic signals via circulating nutrients, hormones and adipokines and drives compensatory adjustments in caloric intake and energy expenditure. Hypothalamic neuropeptides are the crucial regulators of feeding, and their generation and neuronal activities are affected by the metabolic state. ${ }^{8,9)}$ NUCB2 was identified by searching for anorexigenic molecules that were regulated by the activation of peroxisome proliferator-activated receptor- $\gamma .{ }^{24)}$ Nesfatin-1, the amino-terminal fragment peptide of NUCB2, plays a pivotal role in NUCB2-mediated anorexigenic function. ${ }^{24)}$ In this study, the NUCB2 mRNA level was significantly decreased in the hypothalamus of TSOD mice compared with that in TSNO mice after 3 months of age, and this difference was maintained until 12 months of age. This duration was consistent 

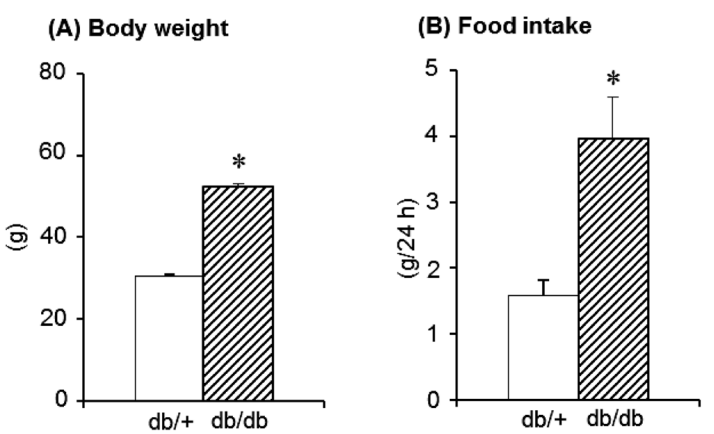

(C) Glucose

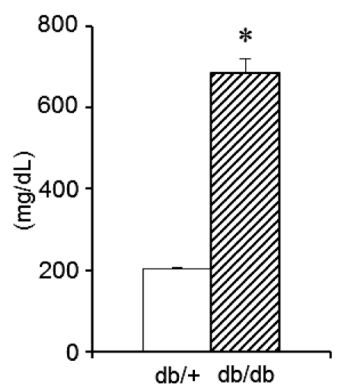

(D) Triglyceride
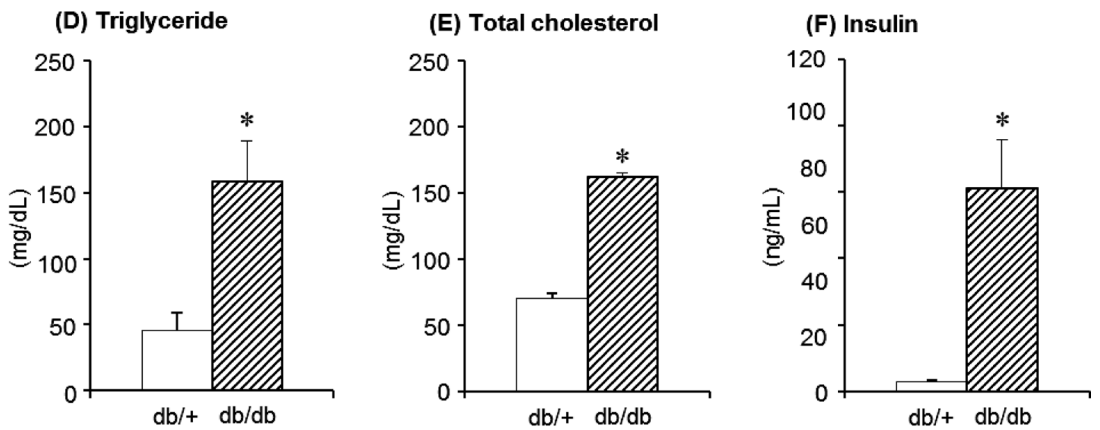

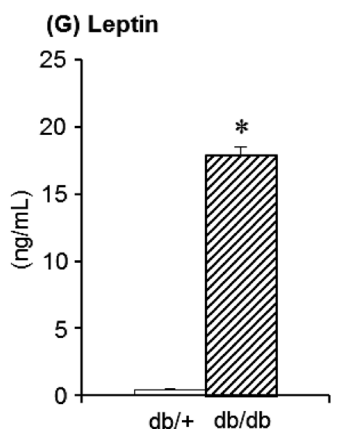

Fig. 5. Diabetic Phenotypes in $d b / d b$ and $d b /+$ Mice

Each column represents the mean with S.E.M. in $d b / d b$ and $d b /+$ mice $(n=10) .{ }^{*} p<0.05 v s . d b /+$ mice $(t$-test)

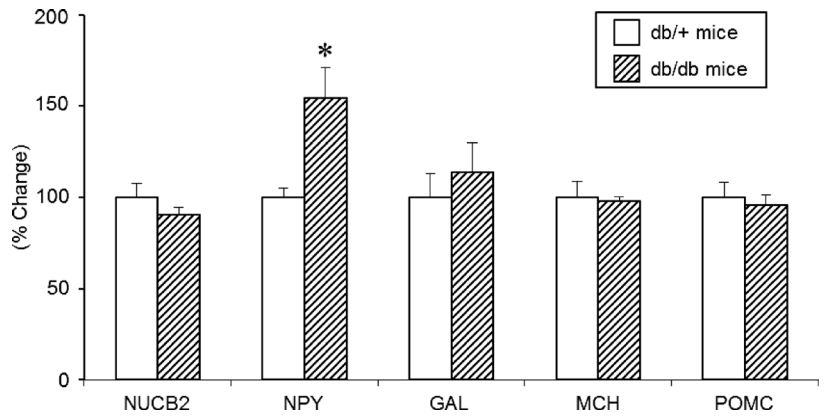

Fig. 6. Expression Levels of NUCB2, NPY, GAL, MCH and POMC mRNA in the Hypothalamus of $d b / d b$ and $d b /+$ Mice

Each column represents the mean with S.E.M. in $d b / d b$ and $d b /+$ mice $(n=7)$. $* p<0.05$ vs. $d b /+$ mice $(t$-test).

with the period in which TSOD mice exhibited hyperphagic feeding and the T2DM phenotype. Importantly, the changes in the expression of the other neuropeptides were not completely consistent with the period in which TSOD mice showed hyperphagic feeding. We also observed that NUCB2 protein was significantly decreased in the hypothalamus of TSOD mice. Therefore, we suggest that NUCB2 synthesis is decreased in the hypothalamus of TSOD mice after 3 months of age, and the hyperphagic feeding in TSOD mice may be mediated by the impaired signaling of hypothalamic NUCB2. Interestingly, there was no difference in the hypothalamic expression of NUCB2 mRNA between $d b / d b$ mice and $d b /+$ mice although $d b / d b$ mice at 3 months of age exhibited marked increases in body weight and plasma levels of glucose, triglyceride, total cholesterol, insulin and leptin which were similar to those in TSOD mice at 7 months of age. It has been reported that the central anorexigenic effects of NUCB2 and nesfatin-1 are elicited by leptin-independent signaling in the hypothalamus but are mediated through the melanocortin system. ${ }^{24,33)}$ Therefore, while TSOD mice and $d b / d b$ mice exhibit a similar metabolic state, they may have different mechanisms that underlie hyperphagic feeding.

The cDNA levels of GAL, MCH, NPY, and POMC were significantly changed in TSOD mice at several ages. However, these did not match the period in which hyperphagic feeding was detected in TSOD mice. Therefore, these neuropeptides 
might be involved in the energy homeostasis in TSOD mice under the limited state. NPY is a well-investigated neuropeptide with an orexigenic effect. ${ }^{23,34)}$ Although NPY immunoreactivity is widely distributed throughout the hypothalamus, in situ hybridization histochemistry has revealed that NPY-expressing neurons are primarily localized in the arcuate nucleus (ARC) and the dorsomedial hypothalamus. ${ }^{35-39)}$ Many model animals of type 2 diabetes such as $d b / d b$ and $o b / o b$ mice demonstrate marked increases in NPY mRNA and peptide in the hypothalamus. ${ }^{40)}$ The genetic removal of NPY partially restored hyperphagic feeding, obesity, hyperglycemia and hyperinsulinemia in $o b / o b$ mice. ${ }^{10)}$ Therefore, the up-regulation of hypothalamic NPY signaling is associated with hyperphagic feeding under the T2DM state. The hypothalamic NPY mRNA in TSOD mice tended to increase at all ages, but the differences were significant only at 7 months of age. TSOD mice showed the highest levels of plasma glucose and insulin at 7 months of age. Therefore, NPY-mediated orexigenic signaling is activated under the severe T2DM state in TSOD mice and contributes to the hyperphagic feeding in TSOD mice in this period.

Hypothalamic GAL exerts an orexigenic effect. ${ }^{15,41-43)}$ In addition to feeding behavior, GAL affects the metabolism, which causes a reduction in energy expenditure and the sympathetic activation of brown adipose tissue. ${ }^{44,45)}$ Interestingly, GAL and NPY play complementary roles with respect to their physiological actions. Hohmann et al. reported that GAL mRNA was increased in the hypothalamus in NPY-deficient mice. ${ }^{46)}$ In this study, expression of the mRNA of GAL was significantly decreased in the hypothalamus of TSOD mice at 3 and 7 months of age. Therefore, the decreased transcription of GAL in the hypothalamus of TSOD mice at the ages of 3 and 7 months might be due to the counteracting regulation against the increased transcription of NPY.

$\mathrm{MCH}$ has a potent orexigenic effect in mammals. Acute, but not repeated, intracerebroventricular administration of $\mathrm{MCH}$ increases feeding in rodents. ${ }^{47)}$ Transgenic mice that overexpress $\mathrm{MCH}$ exhibit the hyperphagic, obese and hyperglycemic phenotypes under feeding with a high-fat diet. ${ }^{17)}$ In addition, $\mathrm{MCH}$ deletion in mice leads to hypophagia and a relative increase in oxygen consumption. ${ }^{48)} \mathrm{MCH}$ is prominently expressed in the lateral hypothalamus, with extensive neuronal projections throughout the central nervous system. ${ }^{49,50)}$ In previous reports, the $\mathrm{MCH}$ mRNA level was up-regulated in the hypothalamus of $o b / o b$ mice compared with that in control $o b /+$ mice $^{51)}$ Since the obese phenotype in $o b / o b$ mice is partially improved by $\mathrm{MCH}$ deficiency, $\mathrm{MCH}$ is a key neuropeptide that acts downstream of leptin and $\mathrm{MCH}$ is required for manifestation of the full $o b / o b$ phenotype. ${ }^{52)}$ In the present study, the MCH mRNA level was significantly decreased in the hypothalamus of TSOD mice at 7 months of age. While the reason for this finding remains unclear, hypothalamic $\mathrm{MCH}-$ mediated signaling might counteract hyperphagic feeding in TSOD mice.

The POMC mRNA level was significantly increased in the hypothalamus of TSOD mice only at 1 month of age. TSOD mice at this age showed normal feeding behavior. POMC is a precursor protein of $\alpha$-MSH which has potent anorexigenic effects. $^{27)}$ POMC expression is closely regulated by leptin signaling in the hypothalamus. Since TSOD mice at 1 month of age exhibit hyperleptinemia, leptin-melanocortin activity might be changed in the hypothalamus in TSOD mice before the development of hyperphagic feeding and the T2DM state. POMC is also known to be a precursor of $\beta$-endorphin and adrenocorticotropic hormone. ${ }^{53)}$ Therefore, we cannot exclude the possibility that the changes in the expression of POMC mRNA in the hypothalamus play some other physiological role in TSOD mice.

The circadian cue affects the expression of hypothalamic neuropeptides. Nocturnal rodents such as mice and rats feed primarily during the dark hours, and characteristically eat their largest meal shortly after onset of the dark phase. ${ }^{54)}$ NPY signaling is required for a circadian cue to increase food intake. ${ }^{55}$ NPY synthesis in the hypothalamus is enhanced before the onset of the dark phase; i.e., a relatively high level of NPY mRNA is detected approximately $4 \mathrm{~h}$ before the onset of the dark phase in the hypothalamus of mice and rats. ${ }^{54,56}$ ) Based on those reports, in this study, hypothalamic tissues were obtained from $4-6 \mathrm{~h}$ before the onset of the dark phase. Therefore, further studies will be needed to clarify the effect of a circadian cue on the expression profile of hypothalamic neuropeptides in TSOD mice.

The NPY mRNA level was significantly increased in $d b / d b$ mice compared with $d b /+$ mice similar to the observation in TSOD and TSNO mice at 7-month-old. The expression of GAL, MCH or POMC mRNA was not different between $d b / d b$ and $d b /+$ mice at this age. These results support our idea that TSOD mice and $d b / d b$ mice may have different mechanisms that underlie hyperphagic feeding while they exhibit a similar metabolic state. It has been reported that $d b / d b$ mice exhibit the increased NPY mRNA level and the decreased POMC mRNA level in the hypothalamus compared with wild type (C57BL/6) mice. ${ }^{57)}$ Different observations between the present and the previous studies may be due to the difference in non -diabetic control mice used ( $d b /+$ or C57BL/6).

In conclusion, the present findings suggest that NUCB2 production in the hypothalamus of TSOD mice is decreased and the disruption of hypothalamic NUCB2-mediated signaling may cause hyperphagic feeding in TSOD mice. In addition, the mechanism that causes hyperphagic feeding in TSOD mice may be different from that in $d b / d b$ mice. Furthermore, TSOD mouse may be a useful animal to investigate the leptin-independent process of hyperphagic feeding, obesity and T2DM.

Acknowledgement The study was supported by the TSOD Mouse Research Fund.

\section{REFERENCES}

1) Srinivasan K, Ramarao P. Animal models in type 2 diabetes research: an overview. Indian J. Med. Res., 125, 451-472 (2007).

2) Suzuki W, Iizuka S, Tabuchi M, Funo S, Yanagisawa T, Kimura M, Sato T, Endo T, Kawamura H. A new mouse model of spontaneous diabetes derived from ddY strain. Exp. Anim., 48, 181-189 (1999).

3) Iizuka S, Suzuki W, Tabuchi M, Nagata M, Imamura S, Kobayashi Y, Kanitani M, Yanagisawa T, Kase Y, Takeda S, Aburada M, Takahashi KW. Diabetic complications in a new animal model (TSOD mouse) of spontaneous NIDDM with obesity. Exp. Anim., 54, 71-83 (2005).

4) Kawada T, Miyata S, Shimada T, Sanzen $Y$, Ito M, Hemmi C, Iizuka S, Suzuki W, Mihara K, Aburada M, Nakazawa M. A study of cardiovascular function in Tsumura Suzuki obese diabetes, a new 
model mouse of type 2 diabetes. Biol. Pharm. Bull., 33, 998-1003 (2010).

5) Hirayama I, Yi Z, Izumi S, Arai I, Suzuki W, Nagamachi Y, Kuwano H, Takeuchi T, Izumi T. Genetic analysis of obese diabetes in the TSOD mouse. Diabetes, 48, 1183-1191 (1999).

6) Miura $T$, Suzuki W, Ishihara E, Arai I, Ishida H, Seino Y, Tanigawa $\mathrm{K}$. Impairment of insulin-stimulated GLUT4 translocation in skeletal muscle and adipose tissue in the Tsumura Suzuki obese diabetic mouse: a new genetic animal model of type 2 diabetes. Eur. J. Endocrinol., 145, 785-790 (2001).

7) Takahashi A, Tabuchi M, Suzuki W, Iizuka S, Nagata M, Ikeya Y, Takeda S, Shimada T, Aburada M. Insulin resistance and low sympathetic nerve activity in the Tsumura Suzuki obese diabetic mouse: a new model of spontaneous type 2 diabetes mellitus and obesity. Metabolism, 55, 1664-1669 (2006).

8) Mercer JG, Speakman JR. Hypothalamic neuropeptide mechanisms for regulating energy balance: from rodent models to human obesity. Neurosci. Biobehav. Rev., 25, 101-116 (2001).

9) Schwartz MW, Porte D Jr. Diabetes, obesity, and the brain. Science, 307, 375-379 (2005).

10) Erickson JC, Hollopeter G, Palmiter RD. Attenuation of the obesity syndrome of $o b / o b$ mice by the loss of neuropeptide Y. Science, 274, 1704-1707 (1996).

11) Kudo $T$, Shimada $T$, Toda $T$, Igeta $S$, Suzuki $W$, Ikarashi N, Ochiai W, Ito K, Aburada M, Sugiyama K. Altered expression of CYP in TSOD mice: a model of type 2 diabetes and obesity. Xenobiotica, 39, 889-902 (2009).

12) Ollmann MM, Wilson BD, Yang YK, Kerns JA, Chen Y, Gantz I, Barsh GS. Antagonism of central melanocortin receptors in vitro and in vivo by agouti-related protein. Science, 278, 135-138 (1997).

13) Kristensen P, Judge ME, Thim L, Ribel U, Christjansen KN, Wulff BS, Clausen JT, Jensen PB, Madsen OD, Vrang N, Larsen PJ, Hastrup S. Hypothalamic CART is a new anorectic peptide regulated by leptin. Nature, 393, 72-76 (1998).

14) Masaki $T$, Yoshimichi G, Chiba $S$, Yasuda $T$, Noguchi H, Kakuma T, Sakata T, Yoshimatsu H. Corticotropin-releasing hormone-mediated pathway of leptin to regulate feeding, adiposity, and uncoupling protein expression in mice. Endocrinology, 144, 3547-3554 (2003).

15) Kyrkouli SE, Stanley BG, Leibowitz SF. Galanin: stimulation of feeding induced by medial hypothalamic injection of this novel peptide. Eur. J. Pharmacol., 122, 159-160 (1986).

16) Moody TW, Merali Z. Bombesin-like peptides and associated receptors within the brain: distribution and behavioral implications. Peptides, 25, 511-520 (2004).

17) Ludwig DS, Tritos NA, Mastaitis JW, Kulkarni R, Kokkotou E, Elmquist J, Lowell B, Flier JS, Maratos-Flier E. Melanin-concentrating hormone overexpression in transgenic mice leads to obesity and insulin resistance. J. Clin. Invest., 107, 379-386 (2001).

18) Ida $T$, Mori K, Miyazato M, Egi $Y$, Abe $S$, Nakahara $K$, Nishihara M, Kangawa K, Murakami N. Neuromedin S is a novel anorexigenic hormone. Endocrinology, 146, 4217-4223 (2005).

19) Hanada R, Teranishi H, Pearson JT, Kurokawa M, Hosoda H, Fukushima N, Fukue Y, Serino R, Fujihara H, Ueta Y, Ikawa M, Okabe M, Murakami N, Shirai M, Yoshimatsu H, Kangawa K, Kojima $\mathrm{M}$. Neuromedin $\mathrm{U}$ has a novel anorexigenic effect independent of the leptin signaling pathway. Nat. Med., 10, 1067-1073 (2004).

20) Tanaka H, Yoshida T, Miyamoto N, Motoike T, Kurosu H, Shibata K, Yamanaka A, Williams SC, Richardson JA, Tsujino N, Garry MG, Lerner MR, King DS, O’Dowd BF, Sakurai T, Yanagisawa M. Characterization of a family of endogenous neuropeptide ligands for the G protein-coupled receptors GPR7 and GPR8. Proc. Natl. Acad. Sci. U.S.A., 100, 6251-6256 (2003).

21) Beck B, Fernette B, Stricker-Krongrad A. Peptide $S$ is a novel potent inhibitor of voluntary and fast-induced food intake in rats. Biochem. Biophys. Res. Commun., 332, 859-865 (2005).
22) Mondal MS, Yamaguchi $H$, Date $Y$, Shimbara $T$, Toshinai $K$, Shimomura Y, Mori M, Nakazato M. A role for neuropeptide W in the regulation of feeding behavior. Endocrinology, 144, 4729-4733 (2003).

23) Stanley BG, Kyrkouli SE, Lampert S, Leibowitz SF. Neuropeptide $\mathrm{Y}$ chronically injected into the hypothalamus: a powerful neurochemical inducer of hyperphagia and obesity. Peptides, 7, 1189-1192 (1986)

24) Oh-I S, Shimizu H, Satoh $T$, Okada $S$, Adachi $S$, Inoue $K$, Eguchi $\mathrm{H}$, Yamamoto M, Imaki T, Hashimoto K, Tsuchiya T, Monden T, Horiguchi K, Yamada M, Mori M. Identification of nesfatin-1 as a satiety molecule in the hypothalamus. Nature, 443, 709-712 (2006).

25) Sakurai T, Amemiya A, Ishii M, Matsuzaki I, Chemelli RM, Tanaka H, Williams SC, Richardson JA, Kozlowski GP, Wilson S, Arch JR, Buckingham RE, Haynes AC, Carr SA, Annan RS, McNulty DE, Liu WS, Terrett JA, Elshourbagy NA, Bergsma DJ, Yanagisawa M. Orexins and orexin receptors: a family of hypothalamic neuropeptides and $\mathrm{G}$ protein-coupled receptors that regulate feeding behavior. Cell, 92, 573-585 (1998).

26) Morley JE, Horowitz M, Morley PM, Flood JF. Pituitary adenylate cyclase activating polypeptide (PACAP) reduces food intake in mice. Peptides, 13, 1133-1135 (1992).

27) Cowley MA, Smart JL, Rubinstein M, Cerdán MG, Diano S, Horvath TL, Cone RD, Low MJ. Leptin activates anorexigenic POMC neurons through a neural network in the arcuate nucleus. Nature, 411, 480-484 (2001).

28) Lechan RM, Fekete C. The TRH neuron: a hypothalamic integrator of energy metabolism. Prog. Brain Res., 153, 209-235 (2006).

29) Wang C, Mullet MA, Glass MJ, Billington CJ, Levine AS, Kotz CM. Feeding inhibition by urocortin in the rat hypothalamic paraventricular nucleus. Am. J. Physiol. Regul. Integr. Comp. Physiol., 280, R473-R480 (2001).

30) Reyes TM, Lewis K, Perrin MH, Kunitake KS, Vaughan J, Arias CA, Hogenesch JB, Gulyas J, Rivier J, Vale WW, Sawchenko PE. Urocortin II: a member of the corticotropin-releasing factor (CRF) neuropeptide family that is selectively bound by type 2 CRF receptors. Proc. Natl. Acad. Sci. U.S.A., 98, 2843-2848 (2001).

31) Chen P, Lin D, Giesler J, Li C. Identification of urocortin 3 afferent projection to the ventromedial nucleus of the hypothalamus in rat brain. J. Comp. Neurol., 519, 2023-2042 (2011).

32) Starr ME, Saito H. Age-Related Increase in Food Spilling by Laboratory Mice May Lead to Significant Overestimation of Actual Food Consumption: Implications for Studies on Dietary Restriction, Metabolism, and Dose Calculations. J. Gerontol. A: Biol. Sci. Med. Sci., in press (2012).

33) Shimizu H, Oh-I S, Hashimoto K, Nakata M, Yamamoto S, Yoshida N, Eguchi H, Kato I, Inoue K, Satoh T, Okada S, Yamada M, Yada T, Mori M. Peripheral administration of nesfatin-1 reduces food intake in mice: the leptin-independent mechanism. Endocrinology, 150, 662-671 (2009).

34) Beck B, Stricker-Krongrad A, Nicolas JP, Burlet C. Chronic and continuous intracerebroventricular infusion of neuropeptide $\mathrm{Y}$ in Long-Evans rats mimics the feeding behaviour of obese Zucker rats. Int. J. Obes. Relat. Metab. Disord., 16, 295-302 (1992).

35) Chronwall BM, DiMaggio DA, Massari VJ, Pickel VM, Ruggiero DA, O'Donohue TL. The anatomy of neuropeptide-Y-containing neurons in rat brain. Neuroscience, 15, 1159-1181 (1985).

36) Gray TS, Morley JE. Neuropeptide Y: anatomical distribution and possible function in mammalian nervous system. Life Sci., 38, 389-401 (1986)

37) Yang L, Scott KA, Hyun J, Tamashiro KL, Tray N, Moran TH, Bi $\mathrm{S}$. Role of dorsomedial hypothalamic neuropeptide $\mathrm{Y}$ in modulating food intake and energy balance. J. Neurosci., 29, 179-190 (2009).

38) White JD, Kershaw M. Increased hypothalamic neuropeptide $Y$ expression following food deprivation. Mol. Cell. Neurosci., 1, 41-48 (1990). 
39) Bi S, Robinson BM, Moran TH. Acute food deprivation and chronic food restriction differentially affect hypothalamic NPY mRNA expression. Am. J. Physiol. Regul. Integr. Comp. Physiol., 285, R1030-R1036 (2003).

40) Beck B. Neuropeptide $Y$ in normal eating and in genetic and dietary-induced obesity. Philos. Trans. R. Soc. Lond. , 361, 1159-1185 (2006).

41) Kyrkouli SE, Stanley BG, Seirafi RD, Leibowitz SF. Stimulation of feeding by galanin: anatomical localization and behavioral specificity of this peptide's effects in the brain. Peptides, 11, 995-1001 (1990).

42) Corwin RL, Robinson JK, Crawley JN. Galanin antagonists block galanin-induced feeding in the hypothalamus and amygdala of the rat. Eur. J. Neurosci., 5, 1528-1533 (1993).

43) Koegler FH, York DA, Bray GA. The effects on feeding of galanin and M40 when injected into the nucleus of the solitary tract, the lateral parabrachial nucleus, and the third ventricle. Physiol. Behav., 67, 259-267 (1999).

44) Menéndez JA, Atrens DM, Leibowitz SF. Metabolic effects of galanin injections into the paraventricular nucleus of the hypothalamus. Peptides, 13, 323-327 (1992).

45) Nagase H, Bray GA, York DA. Effect of galanin and enterostatin on sympathetic nerve activity to interscapular brown adipose tissue. Brain Res., 709, 44-50 (1996).

46) Hohmann JG, Teklemichael DN, Weinshenker D, Wynick D, Clifton DK, Steiner RA. Obesity and endocrine dysfunction in mice with deletions of both neuropeptide Y and galanin. Mol. Cell. Biol., 24, 2978-2985 (2004).

47) Rossi M, Choi SJ, O'Shea D, Miyoshi T, Ghatei MA, Bloom SR. Melanin-concentrating hormone acutely stimulates feeding, but chronic administration has no effect on body weight. Endocrinology, 138, 351-355 (1997).

48) Shimada M, Tritos NA, Lowell BB, Flier JS, Maratos-Flier E. Mice lacking melanin-concentrating hormone are hypophagic and lean.
Nature, 396, 670-674 (1998)

49) Skofitsch G, Jacobowitz DM, Zamir N. Immunohistochemical localization of a melanin concentrating hormone-like peptide in the rat brain. Brain Res. Bull., 15, 635-649 (1985).

50) Bittencourt JC, Presse F, Arias C, Peto C, Vaughan J, Nahon JL, Vale W, Sawchenko PE. The melanin-concentrating hormone system of the rat brain: an immuno- and hybridization histochemical characterization. J. Comp. Neurol., 319, 218-245 (1992).

51) Qu D, Ludwig DS, Gammeltoft S, Piper M, Pelleymounter MA, Cullen MJ, Mathes WF, Przypek R, Kanarek R, Maratos-Flier E. A role for melanin-concentrating hormone in the central regulation of feeding behaviour. Nature, 380, 243-247 (1996).

52) Segal-Lieberman G, Bradley RL, Kokkotou E, Carlson M, Trombly DJ, Wang X, Bates S, Myers MG Jr, Flier JS, Maratos-Flier E. Melanin-concentrating hormone is a critical mediator of the leptin-deficient phenotype. Proc. Natl. Acad. Sci. U.S.A., 100, 10085-10090 (2003).

53) Mountjoy KG, Wong J. Obesity, diabetes and functions for propiomelanocortin-derived peptides. Mol. Cell. Endocrinol., 128, 171-177 (1997).

54) Stütz AM, Staszkiewicz J, Ptitsyn A, Argyropoulos G. Circadian expression of genes regulating food intake. Obesity (Silver Spring), 15, 607-615 (2007).

55) Sindelar DK, Palmiter RD, Woods SC, Schwartz MW. Attenuated feeding responses to circadian and palatability cues in mice lacking neuropeptide Y. Peptides, 26, 2597-2602 (2005).

56) Akabayashi A, Levin N, Paez X, Alexander JT, Leibowitz SF. Hypothalamic neuropeptide $\mathrm{Y}$ and its gene expression: relation to light/ dark cycle and circulating corticosterone. Mol. Cell. Neurosci., 5, 210-218 (1994)

57) Jiang L, You J, Yu X, Gonzalez L, Yu Y, Wang Q, Yang G, Li W, Li C, Liu Y. Tyrosine-dependent and -independent actions of leptin receptor in control of energy balance and glucose homeostasis. Proc. Natl. Acad. Sci. U.S.A., 105, 18619-18624 (2008). 